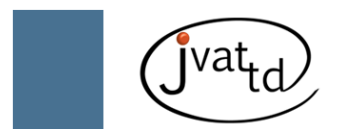

\title{
Destruction of immunobiologicals and their disposal
}

\author{
Gatti MAN (1), Cardoso SNM (1), Simeão SFAP (1), Vitta A (1), Monteiro LM (2)
}

(1) Sacred Heart University (USC), Bauru, São Paulo State, Brazil; (2) Undergraduate Nursing Program, Sacred Heart University (USC), Bauru, São Paulo, Brazil.

\begin{abstract}
The guidelines of the Brazilian National Health System (SUS) state that the municipal authorities are responsible for the vaccination of the population. The present study examined the types of immunobiologicals, amounts and reasons for their destruction and disposal by the Municipal Health Secretariat in the city of Bauru, São Paulo state, Brazil, between 2008 and 2009. This study comprises a descriptive, exploratory and retrospective work that employed search of bibliographic data, collection of secondary data from forms of immunobiologicals disposal and interview of the agent responsible for the disposal of these products in the municipality. It was observed that the total numbers of unused vaccines in 2008 and 2009 were similar (4523 and 4395, respectively), being the most discarded: the diphtheria, tetanus and pertussis (DTP) vaccine in 2008 and DTP, BCG and influenza in 2009. It was found that the amount of discarded vaccines could be reduced since the reasons for that were predictable. Moreover, the current study emphasized that although there is a municipal regulation for the disposal of immunobiologicals, the city still requires a better structure to handle such problem.
\end{abstract}

Key words: immunization, biologic waste disposal, health services.

Vaccines are pharmaceutical products produced by national and international laboratories, which have in their composition immunizing agents such as molecules, inactivated microorganisms, live attenuated viruses, that are designed to protect individuals against certain diseases through the induction of a response from the immune system (1-3). The supply of vaccines should be centralized, since it is the responsibility of the federal government, which is also in charge of coordinating its distribution, leaving to the municipality the implementation of vaccination programs, in a decentralized manner (4).

The waste of biological products remains a major problem in Brazil, mainly due to inadequate storage, exposure to temperature variations, expiration date and the lack of professionals trained to handle the immunobiologicals (resulting in broken bottles, inadequate dilution, contamination and incorrect application techniques) (5).

The residues of vaccines in their opened vials are considered infectious waste that may cause diseases, since most of them have in their compositions attenuated live microorganisms such as the vaccines against poliomyelitis, measles, rubella and yellow fever. Thus, the inappropriate handling of such heath care waste becomes a potential health risk to the population and constitutes an important source of environmental contamination $(6,7)$.

The identification of the causes that lead to the destruction of unused vaccines is important in order to develop preventive measures against the loss of immunobiologicals. The present study examined the types of vaccines, amounts and 
reasons for their destruction and disposal by the Municipal Health Secretariat in the city of Bauru, SP, Brazil.

This study was a descriptive retrospective work, carried out between 2008 and 2009, based on data collection in the Department of Public Health (DPH) of Bauru city. The main information comprised: characteristics of unused vaccines that were discarded (name of the vaccine, origin of the immunobiological, form of presentation, quantity, batch number, expiration date, manufacturer, cost and reason for destruction) and reporting forms that identified the unit and city from which the vaccine was from, amount of used/unused doses, and storage temperature.

In addition, a semi-structured interview with the agent responsible for the discard of vaccines was carried out on the following topics: Does the destruction of immunobiologicals occur in the health units of the municipality? Do you consider the number disposals appropriate? Why? Is there any procedure to prevent the discard of vaccines in the health units? What is it? And to verify if the amount of discarded vaccines in the city was adequate or not, a resolution (RDC n. 306/04) by the Brazilian National Health Surveillance Agency (Anvisa) was consulted.

The present study was approved by the Ethics Research Committee of Sacred Heart University (protocol number 96/2010).
We found out that the amount of unused vaccines in Bauru, between 2008 and 2009, was 8918 vials, more specifically, in 20084523 vials (51\%) were discarded whereas in 20094395 vials $(49 \%)$ were destructed. When separated by type of immunobiological, it was observed that in 2008 the diphtheria, tetanus and pertussis (DTP) vaccine and the polio vaccine were more frequently discarded, respectively with 1527 vials (34\%) and 910 vials (20\%) rejected. In 2009, the figures of destroyed immunobiologicals were: 1189 vials of DTP (27\%), 1259 vials of BCG (28\%) and 587 vials of influenza vaccine (13\%), as displayed in Figure 1.

Vaccines must be discarded for various reasons. The DTP vaccine, for example, must be destroyed four weeks after its vial was opened. Moreover, both extremely low and elevated temperatures inactivate the vaccine components (8). The rate of disposal of the oral polio vaccine, which is a live-attenuated vaccine, is high because its vials must not come into contact with moving surfaces, instruments and the child's mouth. Opened vials should be used within a week, if they are free of contamination and stored at proper temperature $\left(2^{\circ} \mathrm{C}\right.$ to $\left.8^{\circ} \mathrm{C}\right)(8)$.

The hepatitis $\mathrm{B}$ vaccine is multi-dose, and after it is opened, it may be used until the end of shelf life following a strict control of storage temperature $\left(2^{\circ} \mathrm{C}\right.$ to $\left.8^{\circ} \mathrm{C}\right)(8)$.

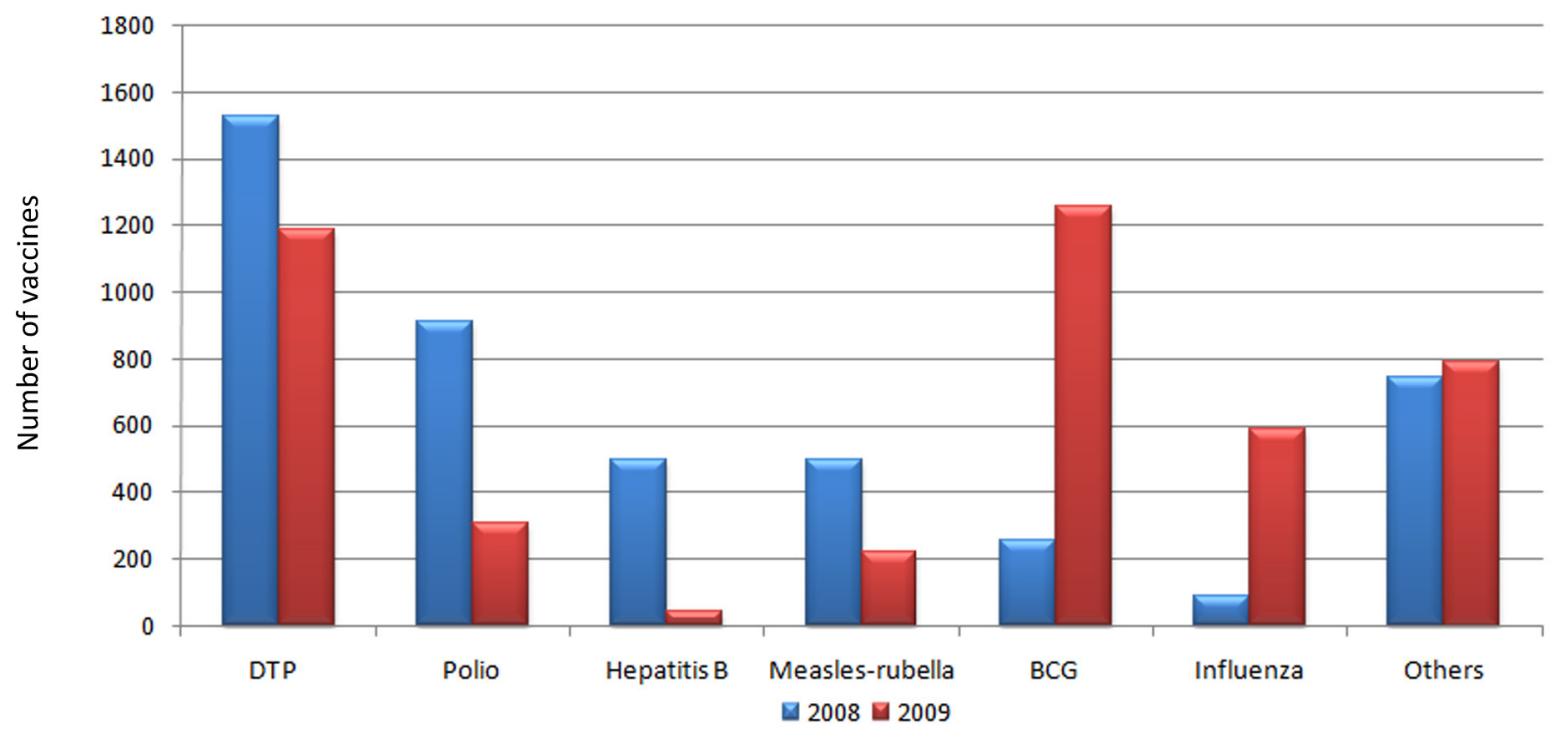

Figure 1. Types and amount of unused vaccines in 2008 and 2009 in Bauru city. 
Measles-rubella (MR) is a lyophilized vaccine that contains live attenuated virus. It must be reconstituted prior to application with diluents. After the dilution, the $\mathrm{MR}$ vaccine must be properly refrigerated $\left(2^{\circ} \mathrm{C}\right.$ to $\left.8^{\circ} \mathrm{C}\right)$ and administered within eight hours (9).

BCG is a lyophilized vaccine obtained by the attenuation of Mycobacterium bovis. Its reconstitution should be carefully done to obtain complete homogenization. It must be stored in refrigerators at $2^{\circ} \mathrm{C}$ to $8^{\circ} \mathrm{C}$ and protected from direct sunlight, which inactivates its properties (8). When reconstituted, BCG vaccine should be used within six hours and discarded after this period. The influenza vaccine is composed of different strains of inactivated virus and must be stored between $2^{\circ} \mathrm{C}$ to $8^{\circ} \mathrm{C}$ and never frozen (8).

The disposal of residues from the vaccination room must be done properly, in order to avoid contaminating nursing professionals, the environment and the population in general. Several people come in contact with the waste produced in the vaccination room, thus they are exposed to the risk of infection if the material is not adequately handled (10). In Brazil, although occupational accidents with exposure to biological material are frequent, there is no official assessment of the number of affected workers and the consequences of these injuries, which hinders the planning and adoption of preventive measures (11).

In a study carried out with nursing professionals that were involved in the Family Health Program, it was observed that the waste produced in vaccination rooms, particularly the disposal of immunobiologicals, was not receiving the proper treatment, being discarded without any procedure (10).

Regarding the reasons for discard of vaccines (displayed in Figure 2), the most important were: expiration dates (64\%), electricity failure with no prior notice $(15 \%)$, and a problems in the wiring of the health unit (9\%).

The immunobiologicals are a distribution system of a logistic chain, which starts in the central warehouse, through the intermediate facilities up to the Basic Health Units that are responsible for the distribution. Therefore, one of the greatest challenges of logistics of vaccines in Brazil is the continental size of the country, which impairs rapid transportation. Numerous vaccines are almost expired when they arrive at their

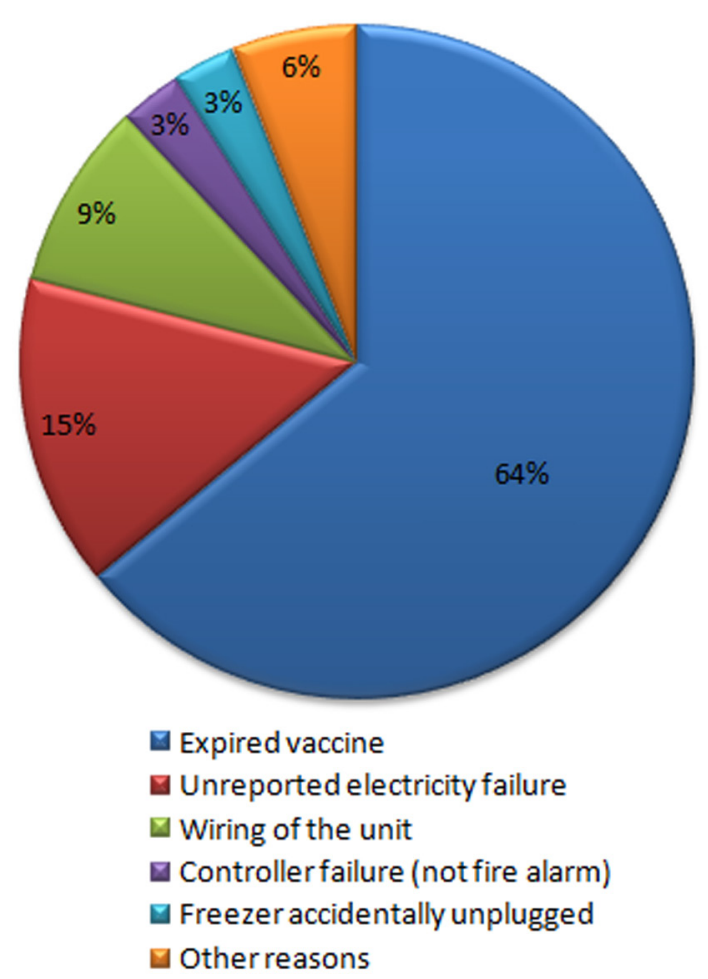

Figure 2. Reasons for the destruction of immunobiological products in 2008 and 2009, in Bauru city.

destination, which explains the large amount of immunobiologicals discarded $(12,13)$.

Immunobiological products are thermolabile and require a rigorous system of conservation, since changes in the temperature may affect their effectiveness, and cause local reactions postvaccination in patients $(13,14)$.

Electricity failure with no prior notice from electric power companies do not allow health units to stock ice packages as an attempt of delaying the internal heating of the freezer. Such measure will preserve the internal temperature of the freezer around $4^{\circ} \mathrm{C}$ for six hours in environments that are between $25^{\circ} \mathrm{C}$ and $28^{\circ} \mathrm{C}$, if the freezer is kept closed (15).

Efforts made by the Brazilian Ministry of Health to match the Cold Chain of the National Program of Immunobiologicals are meaningless, if local authorities are not concerned about making their employees aware of the importance of preventive maintenance of electrical equipment and wiring of the health units. The lack of immediate technical support in health units generates, besides the economic losses, the augmentation in the disposal of immunobiologicals (16-18). 
According to the agent responsible for the disposal of immunobiologicals in Bauru, the discard of vaccines in the municipality is documented in basic health units. Although he considers the amount of discarded products within the expected, he believes that the final number could be reduced with preventive maintenance of equipment and acquisition of generators for the health basic units. He also supposes that the creation of a logistics system that reduces the time spent on the transport of immunobiologicals could prevent the loss of these products, since the expiration date is one of the main reasons for their discard. Regarding electricity failure, little can be done since the city depends on the notification of electric power companies.

Concerning the disposal of vaccines and other supplies (needles, syringes, gloves etc.), the agent states that basic health units follow the resolution (RDC n. 306/04) by the Brazilian National Health Surveillance Agency (Anvisa). The professionals responsible for vaccination rooms are aware of the vulnerability of the vaccines, so their remains are daily discarded and the immunobiologicals are destroyed as follows: the vials and sharp materials are disposed of in proper containers (Descarpack ${ }^{\circledast}$ ) and other materials are placed in white bags, suitable for contaminated waste. The materials are forwarded to the Municipal Health Department, which outsources the final destination of these products.

Based on the present results, it can be concluded that although the amount of discarded vaccines in Bauru, between 2008 and 2009, is within the ordinary range, it could be reduced, since most of the disposals were caused by preventable reasons such as expiration date, wiring of the health unit and electricity failure.

It is hoped that the current study raise awareness among health managers to the issue, in order to prevent destruction of immunobiologicals and, therefore, reduce the amount of waste from health services as well as environmental pollution.

\section{COPYRIGHT}

(c) CEVAP 2011

\section{SUBMISSION STATUS}

Received: June 6, 2011.

Accepted: October 3, 2011.

Abstract published online: October 26, 2011.

Full paper published online: November 30, 2011.

\section{CONFLICTS OF INTEREST}

There is no conflict.

\section{FINANCIAL SOURCE}

Sacred Heart University (USC) provided the financial grants.

\section{ETHICS COMMITTEE APPROVAL}

The present study was approved by the Ethics Research Committee of Sacred Heart University (protocol number 092/2010).

\section{CORRESPONDENCETO}

MÁRCIA APARECIDA N. GATTI, Universidade do Sagrado Coração, Bauru, SP, Brasil. Phone: +55142107 7232 or 9711 0086. Email: marcia. gatti@usc.bror marciagatti-prof@hotmail.com.

\section{REFERENCES}

1. Aranda CMSS, Moraes JC. Rede de frio para a conservação de vacinas em unidades públicas do município de São Paulo: conhecimento e prática. Rev Bras Epidemiol. 2006;9(2):172-185.

2. Fundação Oswaldo Cruz. Vacinas: produção, o que são e história [Internet]. Rio de Janeiro: Instituto de Tecnologia em Imunobiológicos, Bio-Manguinhos; [200-]. [updated 2009 Out 12]. Available from: http://www.fiocruz.br/bio/cgi/cgilua.exe/sys/start. htm?sid=170.

3. Silva LJ. Vacinação, segurança de imunobiológicos e direitos do cidadão. Rev Saúde Pública. 1996;30(4):297-8.

4. Brasil. Senado Federal. Subsecretaria de Informações. Lei No 2.187 de 16 de fevereiro de 1954. Cria o Laboratório Central de Controle de Drogas e Medicamentos, e dá outras providências [Internet]. Brasília, DF: Diário Oficial [da] República Federativa do Brasil; 1954. [update 2009 Nov 02]. Available from: http://www6.senado.gov.br/legislacao/ ListaTextoIntegral.action?id=83019.

5. Brasil. Ministério da Saúde. Manual de procedimentos para vacinação [Internet]. 4 vol. Brasília, DF: Fundação Nacional da Saúde; 2001. [updated 2009 Out 25]. Available from: http://portal.saude.gov.br/ portal/arquivos/pdf/aspectos_tecnicos.pdf.

6. Agência Nacional de Vigilância Sanitária. Resolução RDC no 306, de 07 de Dezembro de 2004. Dispõe sobre o regulamento técnico para o gerenciamento de resíduos de serviços de saúde [Internet]. Brasília, DF: Diário Oficial da República Federativa do Brasil; 2004. [updated 2009 Mar 01]. Available from: http://cfo.org. br/wp-content/uploads/2009/10/resolucao_rdc_306_ ANVISA_2004.pdf.

7. Zamoner M. Modelo para avaliação de planos de gerenciamento de resíduos de serviço de saúde (PGRSS) para Secretarias Municipais de Saúde e/ou do Meio Ambiente. Cienc Saúde Coletiva. 
2008;13(6):1945-52.

8. Kemps B, Farhat CK, Pannuti CS, Aranda CMSS. Norma técnica do programa de imunização [Internet]. São Paulo: Centro de Vigilância Epidemiológica "Prof. Alexandre Vranjac"; 2008. 68 p. [updated 2009 Out 25]. Available from: ftp://ftp.cve.saude.sp.gov.br/doc_ tec/imuni/imuni08_ntprog.pdf.

9. Secretaria da Saúde do Estado de Goiás. Vacina dupla viral - informe técnico [Internet]. Goiás: Secretaria da Saúde do Estado de Goiás. Coordenação Estadual de Imunização; 2008. [updated 2010 Nov 19]. Available from: http://www.sgc.goias.gov.br/upload/links/ arq_859_VacinaADuplaAViralA-AInformeATecnico. doc.

10. Feitosa LR, Feitosa JA, Coriolano MWL. Conhecimentos e práticas do auxiliar de enfermagem em sala de imunização. Cogitare Enferm. 2010;15(4):695-701.

11. Marziale MHP, Silva EJ, Haas VJ, Robazzi MLCC. Acidentes com material biológico em hospital da Rede de Prevenção de Acidentes do Trabalho - REPAT. Rev Bras Saúde Ocup. 2007;32(115):109-19.

12. Coelho Netto G. Contribuição para melhorar o gerenciamento logístico da cadeia de frio de imunobiológicos no Programa de Imunização do Brasil. [master's thesis]. Brasília, DF: Departamento de Engenharia Civil e Ambiental da Universidade de Brasília; 2008. 136 p.

13. Ponte CF. Vacinação, controle de qualidade e produção de vacinas no Brasil a partir de 1960. Hist Cienc Saúde Manguinhos. 2003;10(Suppl. 2):619-53.
14. Gatti MAN. Concepção sobre vacinas e condições de vida: estudo das famílias de crianças faltosas à vacinação, Bauru-SP, 2000. [master's thesis]. Botucatu, SP: Faculdade de Medicina da Universidade Estadual Paulista; 2001. 103 p.

15. Novaes MLO, Simonetti VMM, Gonçalves AA. Estoque e previsão da demanda de vacinas: proposta de gestão. In: XI Simpósio de Administração da Produção, Logística e Operações Internacionais SIMPOI FGV, 2008, São Paulo. São Paulo: Faculdade Getúlio Vargas; 2008. 1-12 p.

16. Prefeitura Municipal de Belo Horizonte. Imunização [Internet]. Belo Horizonte, BH: Biblioteca da Secretaria Municipal de Saúde; 2004. [updated 2010 Mai 02]. Available from: http://www.pbh.gov.br/smsa/ biblioteca/protocolos/imunizacao.pdf.

17. Oliveira SA, Homma A, Mahul DC, Loureiro MLP, Camillo-Coura L. Avaliação das condições de estocagem da vacina contra o sarampo nas unidades sanitárias dos municípios de Niterói e São Gonçalo - Estado do Rio de Janeiro. Rev Inst Med Trop São Paulo. 1991;33(4):313-8.

18. Souza FGM, Santos MH, Carvalho VR, Arruda SFS, Motejunas P, Furtado AS. Conservação dos imunobiológicos em unidades básicas de saúde: investigação em área urbana de um município maranhense. In: Anais da 58 ${ }^{\mathrm{a}}$ Reunião Anual da SBPC, 2006. Florianópolis, SC: Universidade Federal de Santa Catarina; 2006. 